3）貧血记関する項目 a)血色素量 b)全血比重 c) 血漿比重 d)血漿蛋白量 e)ヘマトクリット檤

被調查者は 294 人で対象者の $41.1 \%$ であり, 調查時長 期の不在者が 165 人， $23.1 \%$ あった。

調查結果は地理的環境要因によると思われる腰桷，関 節痛, 動绣などの自覚症状が多く, 血圧は海岸部の一般 的傾向として比較的高血圧者が少なく，血色素量と全衈 比重において生理値の下限ないしそれ以下を示すものが 多かった。

\section{5 、へき地住民の健康管理について}

○犬塚忠子, 二塚 信, 高松 誠

(熊大公衛)

熊本県のへき地, 五木村にある某電力会社の從業員と その家族，並びに五木村の一般住民とについて，身体検 查及び健康指導を行なった。各人の指導の成果を全血比 重, $\mathrm{Hb}$ 值学指標にして追い，健康管理の意義を考元 た。会社從業員, 主として男子については，定期健讋や 会社保健婦の指導によって一応健康管理はゆきとどいて いるので，あまり問題はなかったが，その家族の主㷌の 内には貧血のものがかなり見受けられた。これらのもの には医治の针め, 健康指導, 栄養指導をすると共に, 職 場に於いては，多㞳にわたる生活证びに健氺指導をする ことによって，一年後には從業員並びにをの家族の成績 は们上して来た。

一方，一般住民，主として蜄業，日㕍人夫についても 同様に，全血比重， $\mathrm{Hb}$ 值を測り比較すると，主として 主婦は従業員の主婦より低值であった。そとで一般住民 の主婦と県下全域の働く婦人の血液の成績とを比校する と成績に差異があり，へき地主嫌の貧血が注目される。 てれに対して会社保健婦の一般住民への健康指導の進出 を図ったが，種々の困難があり，その成果は期待し党な かった。

\section{6 宮崎県西米良地方の地区診断について 一特に環境衛生学的実態調查一}

○百々栄德，務中昌已，田中正四

(広大公衛)

昭和 41 年 9 月 4 日 9 月 6 日に至る間, 宮崎県西米良 村において，環境衛生に主体をおいた実態調査を行なっ た。当該村は宮崎県の中央部, 西を熊本県と境し, 九州 山脈の尾根に存在し, 地勢急峻, 山地多く, 平担地は極 く僅少である。又薑く椎葉村に源を発した一ツ瀬川が 村の中央を西から東に流れ全体的にダムの村でもある。 人口は，昭和 40 年の国勢調査において，4,107人，1, 123
世帶となっている。应業はわずかの土地を耕す零細な農 業と村の大半を占める山地に依存する林業が大部分を占 めている。ての調查で問題となった点について以下報告 する。

1 炤和35年以降, 日本条地の農村飞於いてみられる ように人口の減少が著しく, 今後も離村する人口が増加 する傾向にあるので，更に人口の減少が大きな問題とな るであらう。

2 兼業農家がふえ, 金融業, 公務員に比して收入が 特に低い。

3 一年間に病気に稀った人は，35\%，そのうち医者 に沴てもらった人は $60 \%$ であり, あとは放置状態となっ ている。又発病率は年命別においては差がなく, 何れの 年命階級も平均に羅病しているてとが窥えた。㩰療所は 2 ケ所存在するが，村の中央の晾療所矢者が1名いる だけで，他の 1 つは医者不在につき使用されていない。

4 いわ的る農夫症の症状を挀光るすのについてみる と, 腰痛 $15 \%$, 肩こり $23 \%$, 手足のしびれ 7\%, 夜間頻 尿, 息切れ, 各々 $5 \%$ 程度であり, 特に30才以上の年令 層において顕著であった。

5 簡易水道は, 村の 2 ケ所仿るが, その管理は必 ずしも良好とは云光ず，谷川の流れを眝溜配水している にすぎない。又一般的に雨後の水質混濁が問題となって いた。

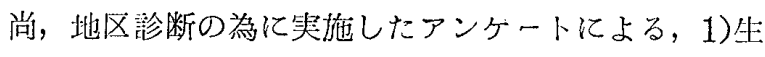
活程度，2)家庭環境衛生状沉，3)優生学的問題，4)目: 衛生，5)栄着状態，についても関連的に考察して秤細を 報告する。

\section{7 農村主婦の生活調查（2）}

○戸次澄美于, 中田襍子，松原文子

（実践女子大）

宮永はる子（杤木県黒磯町高林開拓農協）

前報で, 某開拓部落の農村主婦の学衔状況, 生活状沉 等について調查を行なったが, 今回, 農村主婦の生活活 動によるエネルギー消費量を5月と 8 月の 2 回にわた り, 算出した。更に, 栄養の面については, 栄養調查を 行ない，栄養摆取量及び各栄養素別の分析を行なった。 その結果, 相当量のエネルギー消費があり, 消費熱量に 比して, 栄䬭㩒取量の不足がめだった。更に, 各栄䬭素 については, 特に動物性蛋白質, 脂肪, カルシウム, ビ タミン $\mathrm{B}_{1}, \mathrm{~B}_{2}$ の不足があり，ビタミン $\mathrm{A}$ は，季節による 差がみられた。

以上のととから，農村の生活改善の問題点について 